\title{
Further characterization of the assimilatory nitrate reductase from the yeast Candida nitratophila
}

\author{
Charles R. Hipkin, ${ }^{*}$ David A. KaU $†$ and Andrew C. Cannons $\ddagger$ \\ Biochemistry Research Group, School of Biological Sciences, University of Wales, Swansea, Singleton Park, \\ Swansea SA2 8PP, UK
}

(Received 7 July 1992; revised 4 November 1992; accepted 17 November 1992)

\begin{abstract}
Nitrate reductase from the yeast Candida nitratophila was found to contain one molecule of cytochrome $b_{557}$ and one atom of molybdenum per subunit. FAD/haem-dependent diaphorase activity (haem domain) was associated with a $40 \mathrm{kDa}$ tryptic fragment of the subunit. The 50 amino-terminal residues of this fragment were determined, and the sequence did not show significant similarity to deduced sequences of other nitrate reductases previously published. Increasing ionic strength in vitro had a stimulatory effect on enzymic activity via stimulation of the molybdenum-dependent terminal nitrate-reducing activity. Stimulation of activity by exogenous protein (bovine serum albumin or casein) also appeared to be an ionic effect. Stimulation of catalytic activity by phosphate was a separate effect.
\end{abstract}

\section{Introduction}

Assimilatory nitrate reductase (NR) catalyses the reduction of nitrate to nitrite in certain eukaryotic microorganisms. It has been purified and characterized from several autotrophic sources and it is clear that these NR proteins share similar physical and chemical properties (Solomonson \& Barber, 1990). In addition, the availability of sequences for the NR structural genes from Aspergillus nidulans (Johnstone et al., 1990) and Neurospora crassa (Okamoto et al., 1991) has enabled comparisons to be made between fungal and higher plant NR proteins at the deduced amino acid sequence level (Campbell \& Kinghorn, 1990). Unfortunately, however, many fungal NR proteins are unstable (Horner, 1983) and have been difficult to study in vitro. Consequently,

*Author for correspondence. Tel. (0792) 295361; fax (0792) 295447.

$\dagger$ Present address: Xenova Ltd, 545 Ipswich Road, Slough SL1 4EQ, UK.

$¥$ Present address: Department of Biochemistry and Molecular Biology, University of South Florida, College of Medicine, Tampa, FL 33612, USA.

Abbreviations: ATZ, anilinothiazolinone; BV, benzyl viologen; CR, cytochrome $c$ reductase (partial activity of NR); DITC, $p$-phenylene diisothiocyanate; DCPIP, 2,6-dichlorophenolindophenol; NR, nitrate reductase; PTH, phenylthiohydantoin. there are gaps in our knowledge of their physical and biochemical properties.

Fortunately, NR from the yeast Candida nitratophila is relatively stable in vitro and this has allowed us to study the quaternary structure of the enzyme and its spectroscopic, thermodynamic and kinetic properties (Hipkin et al., 1986, 1989; Hipkin, 1989; Kay et al., 1990). Here, we report further characterization of this fungal enzyme, including studies of structure-function relationships and the effects of exogenous protein and ionic strength on catalytic activity.

\section{Methods}

Organism and culture. Candida nitratophila was obtained from the National Collection of Yeast Cultures, Norwich, UK (catalogue no. 556) and grown at $25^{\circ} \mathrm{C}$ with continuous shaking in an orbital incubator in $250 \mathrm{ml}$ Erlenmeyer flasks (Hipkin et al., 1986) containing $100 \mathrm{ml}$ of Difco Yeast Carbon Base medium $(11.7 \mathrm{~g}$ Difco Yeast Carbon Base $\mathrm{1}^{-1}$ ) with nitrogen supplied as $50 \mathrm{~mm}$-potassium nitrate or $50 \mathrm{~mm}$-ammonium chloride.

Purification of assimilatory nitrate reductase (EC 1.6.6.2). Four litres of ammonium-grown culture was harvested at late exponential phase, washed with distilled water and resuspended for $4 \mathrm{~h}$ in 21 of fresh nitrate medium under growth conditions. This treatment induced high levels of NR activity in the organism. Cells were harvested, washed with distilled water and resuspended in $50 \mathrm{ml} 50 \mathrm{mM}$-potassium phosphate buffer, $\mathrm{pH} 7 \cdot 5$, containing $50 \mu \mathrm{M}-\mathrm{FAD}$ (Buffer A). A cellfree extract was prepared from this suspension after its passage through a French press at $100 \mathrm{MPa}$. The resulting homogenate was centrifuged at $40000 \mathrm{~g}$ at $4{ }^{\circ} \mathrm{C}$ for $25 \mathrm{~min}$ and $\mathrm{NR}$ protein was purified from the 
supernatant by a modification of the method described by Hipkin et al. (1986). The modifications included an initial treatment with $2 \%(w / v)$ protamine sulphate, added $50 \mu \mathrm{l}$ at a time to the stirred, ice-cold extract until a clarified supernatant was obtained after centrifugation at $40000 \mathrm{~g}$. Also, the penultimate blue Sepharose affinity-column run included a $30 \mathrm{ml}$ wash with a high ionic strength buffer $(0.2 \mathrm{M}-$ potassium phosphate buffer, $\mathrm{pH} 7 \cdot 5$, containing $50 \mu \mathrm{M}-\mathrm{FAD}$ )) prior to elution with $0.1 \mathrm{~mm}-\mathrm{NADH}$. Typical preparations were very pure (1000-1200-fold purification) with a final specific activity of 300 $400 \mu \mathrm{mol} \mathrm{min}^{-1}$ (mg protein) ${ }^{-1}$. Such preparations were homogeneous by the criterion of SDS-PAGE giving one band (after staining with Coomassie Blue) corresponding to a size of $98 \mathrm{kDa}$. Electrophoresis and protein determination were done as described previously (Hipkin et al., 1986).

Enzyme assays. NAD(P)H-nitrate reductase [NAD(P)H-NR] activity, $\mathrm{NAD}(\mathrm{P}) \mathrm{H}$-cytochrome $c$ reductase $[\mathrm{NAD}(\mathrm{P}) \mathrm{H}-\mathrm{CR}]$ activity and reduced benzyl viologen-nitrate reductase (BV-NR) activity were measured as described previously (Hipkin et al., 1986). NAD(P)H-NR activity was also determined by following the nitrate-dependent oxidation of $\mathrm{NAD}(\mathbf{P}) \mathrm{H}$ at $340 \mathrm{~nm}$ in $1.0 \mathrm{ml}$ quartz cuvettes containing $50 \mu \mathrm{mol}$ potassium phosphate buffer, $\mathrm{pH} 7 \cdot 5,5.0 \mathrm{nmol}$ FAD, $25 \mu \mathrm{mol}$ potassium nitrate, $2.5 \mathrm{mg}$ bovine serum albumin (BSA) and $0.1 \mu \mathrm{mol}$ NAD(P)H. Reactions were started by the addition of $0 \cdot 05-0 \cdot 1 \mu \mathrm{g}$ of NR.

NAD(P)H-dichlorophenolindophenol reductase $[\mathrm{NAD}(\mathrm{P}) \mathrm{H}-$ DCPIP NR] was determined by following the oxidation of NAD(P)H at $340 \mathrm{~nm}$ in $1.0 \mathrm{ml}$ cuvettes containing $50 \mu \mathrm{mol}$ potassium phosphate buffer, pH 7.5, $5.0 \mathrm{nmol}$ FAD, 0.5 $\mu \mathrm{mol}$ DCPIP, $0.8 \mu \mathrm{mol}$ NAD(P)H and $2.5 \mathrm{mg}$ BSA. Reactions were started by the addition of $0.05-0.1 \mu \mathrm{g}$ NR.

Measurement of molybdenum in NR protein. Molybdenum was determined by atomic absorption spectrophotometry using a Pye Unicam SP9 instrument fitted with a molybdenum Varion Techtron hollow cathode lamp ( $5 \mathrm{~mA})$. Spectrosol molybdenum standard solution $(\mathrm{BDH})$ was used for the preparation of calibration standards. Molybdenum content was also measured by the colorometric method described by Solomonson et al. (1975).

Proteolytic digestion of NR. Freshly purified NR protein was incubated with trypsin ( $5 \mu \mathrm{g}$ per $\mathrm{mg} \mathrm{NR}$ ) in buffer $A$ for $30 \mathrm{~min}$ at $30^{\circ} \mathrm{C}$. Proteolysis was terminated by placing incubation mixtures on ice and adding phenylmethanesulphonyl fluoride to a concentration equivalent to 10 times the weight of the protease. Tryptic fragments generated by short-term digestions were separated by FPLC on a Mono Q HR5/5 anion-exchange column (Pharmacia) at a flow rate of $1 \mathrm{ml} \mathrm{min}{ }^{-1}$. Polypeptide fragments were eluted from the column with a $\mathrm{KCl}$ gradient consisting of an initial $35 \mathrm{ml}$ linear gradient from 0 to $0.4 \mathrm{M}$ followed by a second, $5 \mathrm{ml}$ linear gradient from 0.4 to $1 \mathrm{M}$. The eluate was monitored at $214 \mathrm{~nm}$.

Protein determination. NR protein was estimated by a modification of the method of Bradford (1975) using Bio-Rad reagent. The Bio-Rad microassay was used to determine protein concentrations in the range 5-20 $\mu \mathrm{g}$ and the macroassay was used to determine concentrations in the range $20-100 \mu \mathrm{g}$. Calibration curves were prepared using BSA and purified NR protein (dialysed against water and lyophilized) as standards.

Amino acid sequencing. Tryptic fragments, separated by SDS-PAGE and identified after staining with Coomassie Blue, were cut out of gels, electroeluted and lyophilized. The lyophilized peptide was dissolved in $0.03 \mathrm{ml} 0.2 \mathrm{M}-\mathrm{Na}_{2} \mathrm{HPO}_{4}$ containing $0.25 \%(\mathrm{w} / \mathrm{v})$ SDS and added to $10 \mathrm{mg}$ of DITC glass (17 nm pore size, $200-400$ mesh) prepared by a method modified from Watcher et al. (1973). The glass was incubated for $60 \mathrm{~min}$ at $56^{\circ} \mathrm{C}$ under nitrogen, then washed with water and methanol to remove noncovalently-bound material. The glass-coupled peptide was then sequenced by automated solid-phase Edman degradation (Laursen, 1971) using the microsequence facility built by the SERC Sequence Unit in the Department of Biochemistry, University of Leeds, UK. ATZ-amino acids were converted for $20 \mathrm{~min}$ at $70^{\circ} \mathrm{C}$ (under nitrogen) and the corresponding PTH-amino acids identified by reverse-phase $\left(\mathrm{C}_{18}\right)$ HPLC, using a gradient of acetonitrile in sodium acetate buffer, $\mathrm{pH} 4 \cdot 9$. The PTH-amino acids were quantified at $269 \mathrm{~nm}$ and serine and threonine residues confirmed by detection of their dehydro-derivatives at $313 \mathrm{~nm}$.

\section{Results and Discussion}

\section{Haem and molybdenum content of yeast $N R$}

Spectral properties of yeast NR indicate the presence of cytochrome $b_{557}$ as a prosthetic group (Hipkin et al., 1986; Kay et al., 1990). NR purified in investigations reported here had a $A_{280} / A_{413}$ (Soret) ratio for the oxidized enzyme in the range $2 \cdot 40-2.68$ and $1 \mathrm{mg}$ of pure NR gave an $A_{413}$ of 1.05 absorbance units. Using a value for the extinction coefficient of NR cytochrome $b_{557}$ of $117 \mathrm{~mm}^{-1} \mathrm{~cm}^{-1}$ (Kay et al., 1990), the haem content of the enzyme was calculated to be $0.9 \mathrm{~mol}$ haem per mol NR subunit. The molybdenum content of the enzyme estimated by atomic absorption spectroscopy was $0.71 \mathrm{~g}$ atom per mol NR haem. Colorimetric analysis of a separate, purified preparation indicated a molybenum content of 0.85 g-atom of molybdenum per mol NR haem. These results indicate the presence of one molecule of haem and one atom of molybdenum per NR subunit.

\section{Effect of trypsin on yeast $N R$}

NAD(P)H-NR activity was abolished after yeast NR was incubated with trypsin. However, this treatment had a differential effect on NR partial activities (Table 1). Like NAD(P)H-NR activity, BV-NR activity was inhibited strongly by this treatment but there was a stimulation of the FAD/haem-dependent diaphorase activities of the enzyme by $64 \%$ (NADH-CR) and $25 \%$ (NADH-DCPIP NR).

Separation of tryptic fragments by SDS-PAGE showed that two major peptides were produced, one of

\section{Table 1. Effect of tryptic digestion on NR activities}

NADH-NR activity $=11.75 \mu \mathrm{mol}$ NADH oxidized $\mathrm{min}^{-1}(\mathrm{nmol}$ NR) ${ }^{-1}$

\begin{tabular}{lcccc}
\hline \hline & \multicolumn{4}{c}{ Enzyme activity (\%) } \\
\cline { 2 - 5 } & & NADH-DCPIP & \\
Treatment & NADH-NR & NR & NADH-CR & BV-NR \\
\hline Undigested & 100 & 100 & 100 & 100 \\
Digested & 0 & 125 & 164 & 11 \\
\hline \hline
\end{tabular}




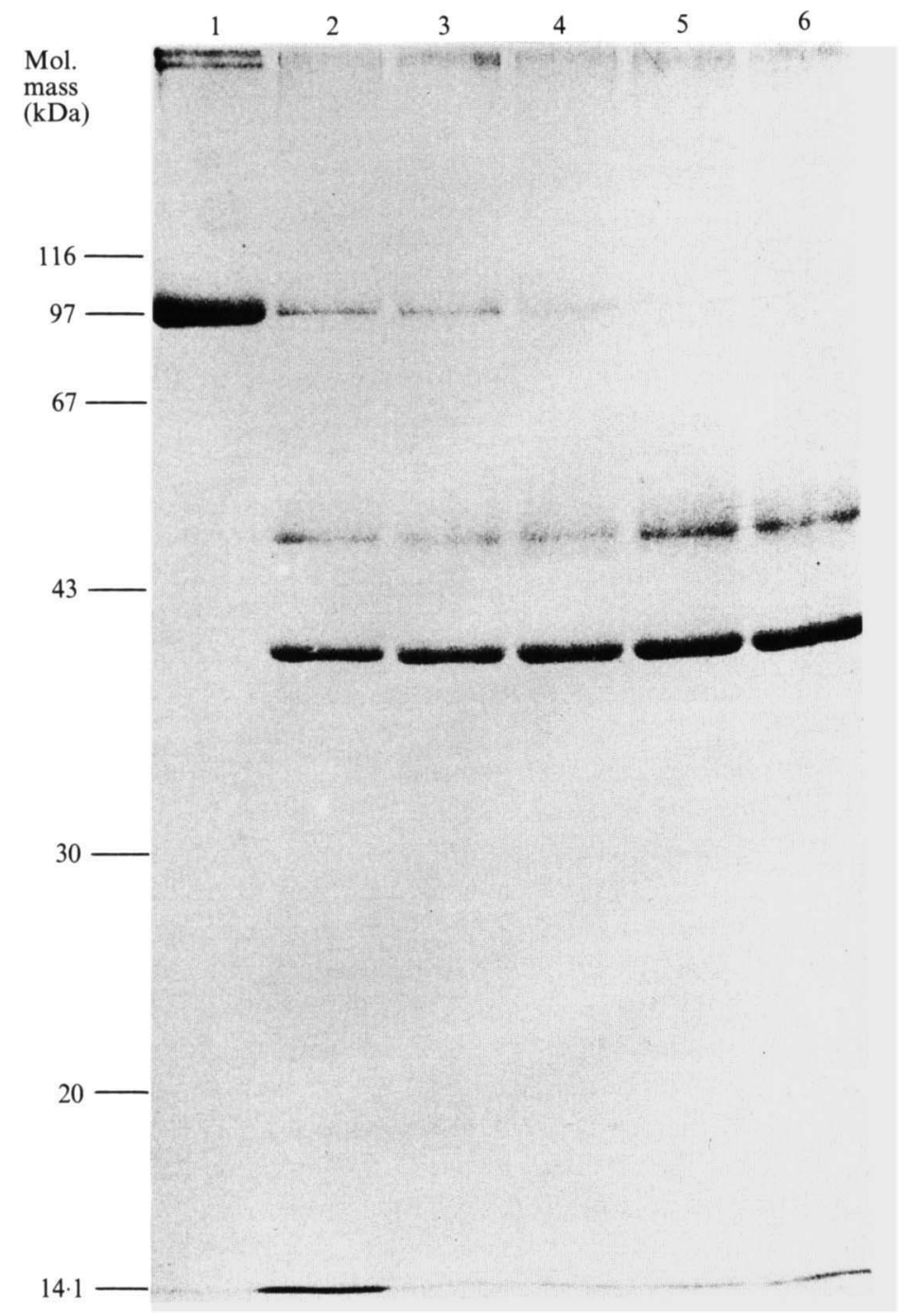

Fig. 1. Tryptic fragments of yeast NR. Yeast NR was incubated with trypsin $\left(5 \mu \mathrm{g}\right.$ trypsin $\left.\mathrm{mg}^{-1}\right)$ for $5,10,15,20$ or 30 min (lanes $2-6$ respectively). Lane 1 shows the undigested $98 \mathrm{kDa}$ subunit. The unequal staining of the two tryptic fragments shown here was not evident in other experiments.
Table 2. Amino acid composition of Candida nitratophila $N R$

\begin{tabular}{lrlc}
\hline \hline Amino acid & Mol \% & Amino acid & Mol \% \\
\hline Aspartic acid & 10.52 & Isoleucine & 4.78 \\
Threonine & 5.40 & Leucine & 6.95 \\
Serine & $7 \cdot 17$ & Tyrosine & 3.43 \\
Glutamic acid & 11.16 & Phenylalanine & 4.61 \\
Proline & 4.72 & Histidine & $2 \cdot 19$ \\
Glycine & 12.83 & Lysine & 7.20 \\
Alanine & 4.50 & Arginine & 3.98 \\
Valine & 7.52 & 1/2 Cysteine & 0.95 \\
Methionine & $2 \cdot 10$ & Tryptophan & ND \\
\hline \hline
\end{tabular}

ND, Not determined.

$40 \mathrm{kDa}$ and one of $50 \mathrm{kDa}$ (Fig. 1). Products produced after a 30 min tryptic digestion were separated by FPLC, which revealed two major peaks. FPLC fractions with diaphorase activity coincided with the first major peak and those with the highest NADH-DCPIP NR activity were pooled and immunoprecipitated with polyclonal NR antibodies (Cannons et al., 1986). Electrophoresis of the immunoprecipitated product yielded a single band at $40 \mathrm{kDa}$. These results indicate that the FAD- and cytochrome $b_{557}$-dependent diaphorase activities of the yeast NR are associated with the $40 \mathrm{kDa}$ tryptic fragment of the enzyme. Unfortunately, the small amount of tryptic fragment obtained after FPLC and immunoprecipitation did not allow us to make reliable estimates of the haem content of this peptide.

Amino acid composition and partial sequence of yeast $N R$

The amino acid composition of acid-hydrolysed yeast NR is shown in Table 2. In the relative composition of acidic and basic amino acids, the yeast enzyme is similar to that from higher plants (Kuo et al., 1980; Redinbaugh \& Campbell, 1985), algae (Giri \& Ramadoss, 1979; 


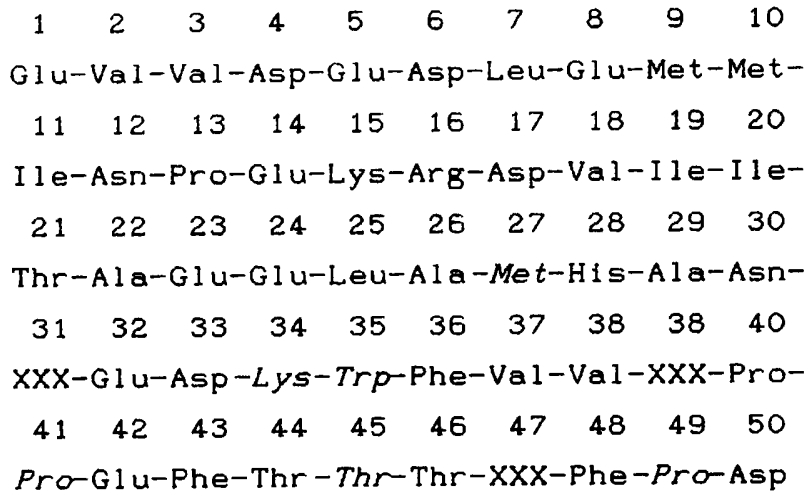

Fig. 2. Partial amino acid sequence of the $\mathrm{N}$-terminal region of the $40 \mathrm{kDa}$ tryptic fragment of $C$. nitratophila NR. Residues designated XXX were not positively identified and residue identities at positions $27,34,35,41,45$ and 49 (italics) are tentative. Residue 27 was identified as lysine in the initial run.

De la Rosa et al., 1981) and Neurospora (Le \& Lederer, 1982).

There were difficulties in obtaining amino acid sequence data using undigested yeast NR, indicating that the $\mathrm{N}$-terminus of the enzyme is blocked. However, the $40 \mathrm{kDa}$ fragment obtained by tryptic digestion gave a single, partial sequence of 36 residues with good yield in an initial cycle (repetitive yield $=93 \%$; initial sequence yield $=72 \mathrm{pmol}$ ). The sequence was extended to 50 residues in a subsequent run and for cycles 2-50 the average repetitive yield was $92 \%$ and the initial yield was $168 \mathrm{pmol}$. There was excellent agreement between both runs and no other $\mathrm{N}$-terminal sequences were detected. The sequence obtained is shown in Fig. 2. The estimated isoelectric point of this sequence is $\mathbf{4 7 2}$. Comparison of this sequence with the deduced amino acid sequences of higher plant and fungal NRs and other proteins stored in the National Research Foundation Protein Library or the GenBank Genetic Sequence Databank, failed to reveal significant similarity.

\section{Effect of ionic strength, phosphate and protein on yeast} NR activity

Kay \& Barber (1986) have shown that increased ionic strength in vitro has a stimulatory effect on the activity of Chlorella NR. We found this also with yeast NR, but only when our assay mixtures did not contain added BSA. At both low $(I=20 \mathrm{~mm})$ and high $(I=100 \mathrm{~mm})$ ionic strength, the $\mathrm{pH}$ optimum of NADH-NR activity was $7 \cdot 0$.

Fig. 3 shows the effect of the presence of BSA in a similar experiment with all assays done at $\mathrm{pH} 7 \cdot 0$. NAD(P)H-NR activity was stimulated by $60 \%$ after an increase in ionic strength from 15 to $100 \mathrm{~mm}$ in assay mixtures which did not include BSA. When BSA was present, there was no such stimulation of NR activity. Further experiments showed that the ionic enhancement effect exhibited in the absence of BSA was only apparent with the terminal nitrate-reducing partial activity (BVNR) of the enzyme (Fig. 4). Increase in ionic strength had little effect on FAD-dependent diaphorase activity (NADH-DCPIP NR).

In our in vitro NR assays with crude extracts and purified fractions, we routinely include BSA (Boehringer Mannheim, protein content $>98 \%$ ) in an assay mixture containing approximately $25 \mathrm{~mm}$-phosphate buffer $(\mathrm{pH} 7.5)$ at final volume, since this enhances enzyme

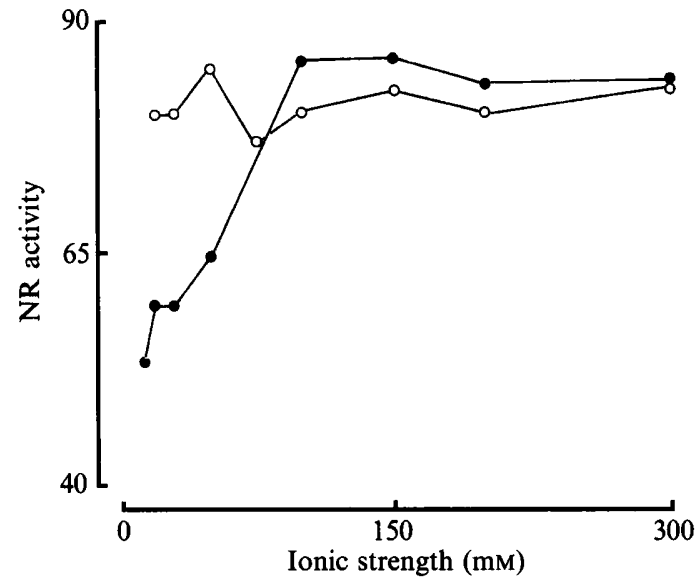

Fig. 3

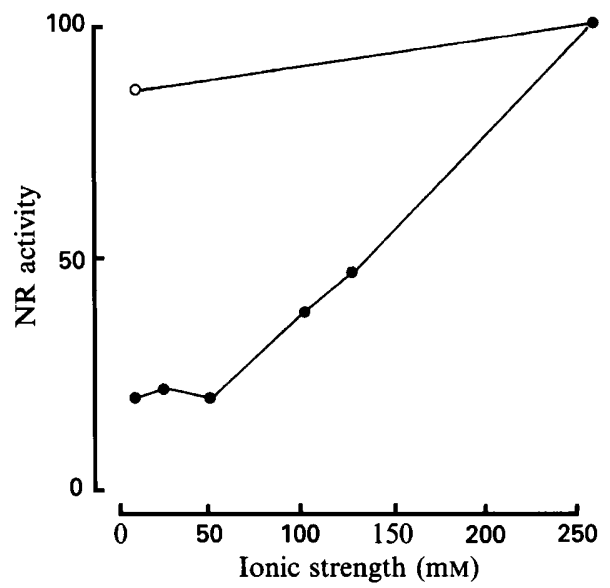

Fig. 4

Fig. 3. Effect of ionic strength on yeast NR activity. NR (0.625 pmol) was assayed at different ionic strengths with BSA present $(O)$ or absent $(0)$ by following the nitrate-dependent oxidation of NADH.

Fig. 4. Effect of ionic strength on partial activities of yeast NR. NR $(0.625 \mathrm{pmol})$ was assayed at different ionic strengths in the absence of BSA. , BV-NR activity; O, DCPIP-NR activity. 


\section{Table 3. Effect of BSA and casein on NR activities}

$100 \%$ NR activity of the enzyme preparation was equivalent to an NADH-NR activity of $324 \mu \mathrm{mol} \mathrm{min}^{-1}$ (mg protein) ${ }^{-1}(a)$ and $300 \mu \mathrm{mol} \mathrm{min}^{-1}$ (mg protein $)^{-1}(b)$.

\begin{tabular}{|c|c|c|c|}
\hline \multirow[b]{2}{*}{$\begin{array}{c}\text { Addition } \\
\text { ( } \mu \text { g per assay) }\end{array}$} & \multicolumn{3}{|c|}{ NR activity (\%) } \\
\hline & $\begin{array}{c}\text { NADH-DCPIP } \\
\text { NR }\end{array}$ & BV-NR & NADH-NR \\
\hline \multicolumn{4}{|l|}{ (a) $B S A$} \\
\hline 0 & 100 & 8 & 40 \\
\hline 5 & 100 & 22 & 46 \\
\hline 10 & 100 & 60 & 66 \\
\hline 50 & 100 & 92 & 100 \\
\hline 100 & 100 & 100 & 100 \\
\hline 250 & 100 & 95 & 100 \\
\hline \multicolumn{4}{|l|}{ (b) Casein } \\
\hline 0 & 100 & 12 & 19 \\
\hline 5 & 100 & 24 & 37 \\
\hline 10 & 100 & 49 & 71 \\
\hline 50 & 100 & 84 & 85 \\
\hline 100 & 100 & 90 & 92 \\
\hline 250 & 100 & 100 & 100 \\
\hline
\end{tabular}

activity in vitro (Hipkin et al., 1986). When BSA was omitted, NR activity was $40 \%$ of the activity obtained in assays containing $50-2500 \mu \mathrm{g}$ BSA (in an assay volume of $700 \mu$ l) (Table 3). NR activity decreased dramatically when the amount of BSA was decreased below $25 \mu \mathrm{g}$ per assay. Moreover, it should be noted that similar increases in NR activity were observed irrespective of whether the BSA preparation had been subject to prior filtration through Superose 6 or not. Furthermore, similar results were obtained when casein was used in place of BSA (Table 3).

Further investigations of the effects of BSA and casein showed that additions of these proteins had a differential effect on the partial activities of the enzyme. As with the increased ionic strength effect, BV-NR activity was stimulated by the addition of extra protein but there was no effect on NADH-DCPIP NR activity (Table 3).

The inclusion of exogenous proteins like BSA in NR extraction and assay buffers in order to enhance activity in crude preparations is not uncommon (Schrader et al., 1974; Purvis et al., 1976), although their role in any activation process that may occur has not been clear. It has been suggested that BSA may protect NR from dissociation into subunits (Purvis et al., 1976). Consequently, since yeast NR exists as a dimer or tetramer in vitro, depending on NR concentration (Hipkin et al., 1986), we tested whether the protein effect described here could have resulted from a change in the quaternary configuration of yeast NR from the dimeric to the tetrameric form at high protein (NR+BSA) concentrations. However, gel-filtration of yeast NR by FPLC using Superose 6 yielded values for the Stokes' radius of $6.3 \mathrm{~nm}$, irrespective of whether the enzyme was chromatographed in the presence or absence of BSA. This indicated that BSA was neither binding to NR nor effecting a change in the quaternary structure of the enzyme, and that the dimer was the predominant form under both conditions.

Since the effects of increased protein and ionic strength were very similar and not additive at optimal concentrations of protein, we suggest that both are types of ionic effects which influence the transfer of electrons from the haem centre to the molybdenum centre of the enzyme, a rate-limiting step in the catalytic turnover of this enzyme (Kay et al., 1990). Therefore, it should be noted that experiments on the effects of increased ionic strength on NAD $(\mathrm{P}) \mathrm{H}-\mathrm{CR}$ activity must be treated with caution, since assay of that partial activity involves supplying a protein (cytochrome $c$ ) as a substrate, which itself may contribute significantly to an ionic effect. This might explain why Barber \& Notton (1990) found that maximum NADH-CR activity in spinach (Spinacea oleracea) was apparently achieved at a lower ionic strength than maximum activity of NADH-DCPIP NR.

Stimulation of NR activity by inclusion of phosphate in assay mixtures has been noted with fungal and algal extracts (Nicholas \& Scawin, 1956; Everest et al., 1984). Therefore, in order to investigate the relationship between phosphate activation and extraneous protein/ ionic effects, the effect of phosphate on yeast NADH-NR activity was also studied. Initial experiments confirmed that phosphate additions to low ionic buffers resulted in activation of NR activity (not shown). Subsequently, high ionic strength assay buffer $(100 \mathrm{mM})$ at $\mathrm{pH} 7.0$ was used and phosphate concentrations were varied from 0-200 mM. Addition of 50-100 mM phosphate resulted in an approximately 3 -fold increase in NR activity. Since the phosphate effect occurs in a high ionic environment and is both larger and more striking than any ionic strength effect we have observed, we concluded that it results from a separate type of enzyme interaction.

It is clear from recent investigations with Chlorella and higher plants that NR proteins from diverse eukaryotic sources show many similarities at the biochemical level (Solomonson \& Barber, 1990). However, despite the rapid advances being made at the molecular-genetic level with some fungal systems, the nonavailability of stable and pure fungal NR has limited the progress of comparative studies at the biochemical level. However, our studies with the yeast Candida nitratophila indicate that fungal NR also shows a large number of similarities with other NR proteins at the biochemical level. We have shown here that yeast NR contains one molecule of haem and one atom of molybdenum per molecule of subunit and that the haem is associated with a $40 \mathrm{kDa}$, C-terminal, tryptic fragment. In addition, as with plant 
NR (Kay \& Barber, 1986; Barber \& Notton, 1990), yeast NR activity is subject to stimulation by increased ionic strength and phosphate.

We have commented previously on the close similarity between yeast NR and Chlorella NR in terms of quaternary structure, thermodynamic properties and the rate-limitation in catalysis imposed by the intramolecular transfer of electrons between the haem and molybdenum centre (Hipkin, 1989; Hipkin et al., 1989; Kay et al., 1990). However, similarities are not apparent when the short sequence of amino acids for the $40 \mathrm{kDa}$ tryptic fragment of yeast NR, discussed here, is compared with the deduced amino acid sequences of other (plant and fungal) NR proteins. A possible explanation for this is that the yeast NR sequence described here is from a trypsin-sensitive hinge region in the C-terminal half of the enzyme - a region where little sequence similarity is apparent when other eukaryotic NR proteins are compared with each other (Campbell \& Kinghorn, 1990).

We are grateful to Dr J. B. C. Findlay and Dr J. N. Keen at the Science and Engineering Research Council Sequencing Unit in the Department of Biochemistry, University of Leeds, for their help in obtaining the partial amino acid sequence of the Candida NR $40 \mathrm{kDa}$ tryptic fragment. Thanks also to Dr Chris Kay (University of South Florida) for his help in the colorimetric analysis of molybdenum. D.A.K. acknowledges receipt of a Science and Engineering Research Council studentship.

\section{References}

Barber, M. J. \& NotTon, B. A. (1990). Spinach nitrate reductase. Effects of ionic strength and $\mathrm{pH}$ on the full and partial enzyme activities. Plant Physiology 93, 537-540.

CAMPBell, W. H. \& KinghORN, J. R. (1990). Functional domains of assimilatory nitrate reductases and nitrite reductases. Trends in Biochemical Science 15, 315-319.

Cannons, A. C., Ali, A. H. \& Hipkin, C. R. (1986). Regulation of nitrate reductase in the yeast Candida nitratophila. Journal of General Microbiology 132, 2005-2011.

De la Rosa, M. A., Vega, J. M. \& ZumfT, W. G. (1981). Composition and structure of assimilatory nitrate reductase from Ankistrodesmus braunii. Journal of Biological Chemistry 256, 5814-5819.

EVEREST, S. A., Hipkin, C. R. \& Syrett, P. J. (1984). The effect of phosphate and flavin adenine dinucleotide on nitrate reductase activity of some unicellular marine algae. Journal of Experimental Marine Biology and Ecology 76, 263-275.

Giri, L. \& Ramadoss, C. S. (1979). Physical studies on assimilatory nitrate reductase from Chlorella vulgaris. Journal of Biological Chemistry 254, 1703-1712.
HIPKIN, C. R. (1989). Nitrate assimilation in yeasts. In Molecular and Genetic Aspects of Nitrate Assimilation, pp. 51-68. Edited by J. L. Wray \& J. R. Kinghorn. Oxford: Oxford Science Publications.

Hipkin, C. R., Ali, A. H. \& Cannons, A. C. (1986). Structure and properties of assimilatory nitrate reductase from the yeast Candida nitratophila. Journal of General Microbiology 132, 1997-2003.

Hipkin, C. R., Kau, D. A., Cannons, A. C., Jones, D. H., Gallon, J. R., Kay, C. J., Barber, M. J. \& Solomonson, L. P. (1989). Physical and chemical properties of nitrate reductase from Candida nitratophila. Biochemical Society Transactions 17, 928-929.

HORNER, R. D. (1983). Purification and comparison of nit-l and wildtype NADPH-nitrate reductase of Neurospora crassa. Biochimica et Biophysica Acta 744, 7-15.

Johnstone, I. L., McCabe, P. C., Greaves, P., Cole, G. E., Brow, M. A. D., GurR, S. J., Unkles, S. E., Clutterbuck, A. J., KINGHORN, J. R. \& INNIS, M. (1990). The isolation and characterization of the crnA-niiA-niaD gene cluster for nitrate assimilation in the filamentous fungus Aspergillus nidulans. Gene 90, 181-192.

KAY, C. J. \& BARBER, M. J. (1986). Assimilatory nitrate reductase from Chlorella: effect of ionic strength and $\mathrm{pH}$ on catalytic activity. Journal of Biological Chemistry 261, 12725-12730.

Kay, C. J., Barber, M. J., Solomonson, L. P., KaU, D. A., Cannons, A. C. \& HIPKIN, C. R. (1990). Spectroscopic, thermodynamic and kinetic properties of Candida nitratophila nitrate reductase. Biochemical Journal 272, 545-548.

Kuo, T., Kleinhofs, A. \& WARner, R. L. (1980). Purification and partial characterisation of nitrate reductase from barley leaves. Plant Science Letters 17, 371-381.

LAURSEN, R. A. (1971). Solid phase Edman degradation. An automated peptide sequencer. European Journal of Biochemistry 20, 89-102.

LE, K. H. D. \& LEDERER, F. (1982). On the presence of a haem-binding domain homologous to cytochrome $b_{5}$ in Neurospora crassa assimilatory nitrate reductase. EMBO Journal 2, 1909-1914.

Nicholas, D. J. D. \& SCAWIN, J. H. (1956). A phosphate requirement for nitrate reductase from Neurospora crassa. Nature, London 178, 1474-1475.

Oкамото, P. M., Fu, Y.-H. \& Marzluf, G. A. (1991). nit-3, the structural gene of nitrate reductase in Neurospora crassa: nucleotide sequence and regulation of mRNA synthesis and turnover. Molecular and General Genetics 227, 213-223.

Purvis, A. C., Tischler, C. R. \& Fites, R. C. (1976). In vitro studies of nitrate reductase activity in cotton cotyledons. Plant Physiology 58, 95-99.

Redinbaugh, M. G. \& CAMPBell, W. H. (1985). Quaternary structure of squash NADH: nitrate reductase. Journal of Biological Chemistry 260, 3380-3385.

Schrader, L. E., Cataldo, D. A. \& Peterson, D. M. (1974). Use of protein in extraction and stabilization of nitrate reductase. Plant Physiology 53, 688-690.

Solomonson, L. P. \& BARBer, M. J. (1990). Assimilatory nitrate reductase: functional properties and regulation. Annual Review of Plant Physiology 41, 225-253.

Solomonson, L. P., Lorimer, G. H., Hall, R. L., Bouchers, R. \& LegGetT BAILEY, J. (1975). Reduced nicotinamide adenine dinucleotide-nitrate reductase of Chlorella vulgaris. Journal of Biological Chemistry 250, 4120-4127.

WATCHER, E., MACHLEIDT, W., HoFNER, H. \& OTto, J. (1973). Aminopropyl glass and its $p$-phenylene diisothiocyanate derivative, a new support in solid phase Edman degradation of peptides and proteins. FEBS Letters 35, 97-102. 